\title{
Extended-spectrum beta-lactamase and Class 1 integrons in multidrug- resistant Escherichia coli isolated from turkeys
}

\author{
Samah Eid ${ }^{1}$ and Abdel Hafeez Samir ${ }^{2}$
}

1. Department of Bacteriology, Reference Laboratory for Veterinary Quality Control on Poultry Production, Animal Health Research Institute, P.O. Box 264, Dokki, Giza 12618, Egypt; 2. Department of Biotechnology, Reference Laboratory for Veterinary Quality Control on Poultry Production, Animal Health Research Institute, P.O. Box 264, Dokki, Giza 12618, Egypt.

Corresponding author: Samah Eid, e-mail: samaheid@ymail.com

Co-author: AHS: abdelhafez_samir@yahoo.com

Received: 13-04-2019, Accepted: 24-06-2019, Published online: 30-07-2019

doi: 10.14202/vetworld.2019.1167-1174 How to cite this article: Eid S, Samir AH (2019) Extended-spectrum betalactamase and Class 1 integrons in multidrug-resistant Escherichia coli isolated from turkeys, Veterinary World, 12(7): 1167-1174.

\begin{abstract}
Aim: This study aimed to investigate the prevalence and implication of extended-spectrum beta-lactamase (ESBL) producing and Class 1 integrons (int 1 ) gene carriers Escherichia coli isolates that demonstrated multidrug resistance (MDR) phenotypes and was isolated from turkeys that suffered from respiratory manifestations.

Materials and Methods: A total of 120 freshly dead turkey poults that suffered from respiratory manifestations, with a history of treatment failure at Hefna, Belbis, Sharqia (Egypt) were sampled. From each bird lung and liver were aseptically collected and transported for laboratory investigations.

Results: Examination of samples collected from 120 freshly dead turkey poults revealed the isolation of coagulase-positive staphylococci, coagulase-negative staphylococci, Campylobacter spp., Salmonella spp., Proteus spp., Pseudomonas spp., Klebsiella spp., and E. coli with the prevalence rates of 12/120 (10\%), 30/120 (35\%), 17/120 (14.2\%), 5/120 (4.1\%), $17 / 120(14.2 \%), 6 / 120(5 \%), 7 / 120(5.8 \%)$, and 18/120 (15\%), respectively. E. coli isolates were subjected for serotyping and characterization, while the rest of isolates were preserved to be investigated later in further studies. Serogrouping of E. coli isolates revealed the identification of O119, O6, O8, and O169, while 1/18 of isolates was untypable. Studying phenotypic antibiotic susceptibility profiles of isolates revealed that 18/18 (100\%) of isolates demonstrated resistance against cefuroxime, tetracycline, and trimethoprim, 16/18 (88.9\%) of isolates demonstrated resistance to amoxicillin/clavulanic acid, enrofloxacin, and norfloxacin, 14/18 (77.8\%) of isolates demonstrated resistance to doxycycline and ciprofloxacin, and $9 / 18(50 \%)$ of isolates showed resistance to gentamycin. Double disk synergy test showed that 6/18 (33.3\%), 8/18 (44.4\%), and $13 / 18(72.2 \%)$ of isolates demonstrated the phenotypic pattern of ESBL producers with cefepime, cefotaxime, and ceftriaxone, respectively. Genotypic attributes for beta-lactamase TEM gene and int 1 gene were studied by polymerase chain reaction and revealed that $17 / 18(94.4 \%)$ of isolates were positive for both genes. Embryo lethality test indicated that the 18 studied $E$. coli isolates were considered primary pathogens.
\end{abstract}

Conclusion: The results revealed that 18/18 (100\%) of E. coli isolates demonstrated MDR against three or more antibiotic groups, $9 / 18(50 \%)$ of isolates showed extensive resistance against the nine tested chemotherapeutic agents from seven antibiotic groups. It is recommended to monitor the circulation of MDR and ESBL-producing pathogens in poultry production in a one health approach, as a preventive measure to mitigate the risk imposed on public health.

Keywords: Class 1 integrons, Escherichia coli, extended-spectrum beta-lactamase, multidrug resistance, turkeys.

\section{Introduction}

Escherichia coli is considered one of the normal intestinal microbiota in human and animals including poultry species. In this regard, food safety and quality monitoring measures account on the detection of E. coli as an indicator of fecal contamination and hygiene throughout the food chain. It is also of significance to monitor the circulation of antibiotic-resistant strains and resistance genes from the animal side including poultry to human side, especially as E. coli can play the role of

Copyright: Eid and Samir, Open Access. This article is distributed under the terms of the Creative Commons Attribution 4.0 International License (http://creativecommons.org/licenses/ by/4.0/), which permits unrestricted use, distribution, and reproduction in any medium, provided you give appropriate credit to the original author(s) and the source, provide a link to the Creative Commons license, and indicate if changes were made. The Creative Commons Public Domain Dedication waiver (http:// creativecommons.org/publicdomain/zero/1.0/) applies to the data made available in this article, unless otherwise stated. primary or secondary pathogen in a way that imposes a major risk for human health and poultry production.

Recently, extended-spectrum beta-lactamase (ESBL)-producing microorganisms have attracted the global concern in veterinary medicine [1]. ESBLproducing bacteria refer to the ability of those producers to hydrolyze a broad spectrum of beta-lactam antimicrobials as clavulanic acid [2]. In this regard, E. coli among members of Enterobacteriaceae family are considered ESBL producers. ESBLs degrade oxyimino-cephalosporin (cefotaxime [CTC] and ceftazidime) and they are defined as $\beta$-lactamases that confer resistance to bacteria against the penicillins, the first-generation, second-generation, and third-generation cephalosporins by hydrolyzing these antibiotics. Thus, ESBL is claimed to be responsible for treatment failure against antibiotics such as CTC and ceftazidime, the most prescribed cephalosporins 
for the treatment of highly dangerous human infections; consequently, resistance against this group of antibiotics is of high significance. ESBLs are defined as $\beta$-lactamases that confer resistance to bacteria against the penicillins, the first, second, and third-generation cephalosporins. Organisms with high ampicillin $\mathrm{C}(\mathrm{AmpC})$ activity can give positive ESBL screening since they are active on cephalosporins, whereas they fail to confirm the clavulanic acid screening test as ESBLs can be inactivated by clavulanic acid, while the AmpCs cannot [1]. Contamination of poultry products by ESBL during the slaughtering process was associated with misuse of antibiotics in rearing cycles [3]. Other researchers reported the isolation of ESBL from the gastrointestinal tract of livestock, including turkey flocks [4].

Thus, the present study aimed to investigate the circulation of ESBL-producing integrons one carriers and antibiotic-resistant $E$. coli in turkey flocks and to recommend the most suitable antibiotic treatment.

\section{Materials and Methods}

\section{Ethical approval}

No live birds were used or involved in the study. Freshly dead turkey poults were collected from farms in sterile plastic bags and transported in ice boxes to laboratory within $24 \mathrm{~h}$ for examination and testing.

\section{Sampling}

A total of 120 freshly dead turkey poults were sampled to investigate the causative agents and to propose effective antibiotic medication. From each bird lung and liver were aseptically collected and transported for laboratory testing. The reported case history was respiratory manifestations, depression, anorexia, nasal discharge, and high morbidity and mortality rates. The turkey farms are located at Hefna, Belbis, Sharqia (Egypt).

\section{Isolation and identification of $E$. coli isolates}

Samples were investigated for $E$. coli isolation according to Barnes and Gross [5], Salmonella spp. according to ISO/IEC [6], staphylococci species according to ISO/IEC [7], Proteus spp., Klebsiella spp., and Pseudomonas spp. according to Saif [8], and Campylobacter spp. according to ISO [9].

\section{Serotyping of $E$. coli isolates}

Serotyping of $E$. coli isolates was applied in the Reference Laboratory for Veterinary Quality Control on Poultry Production, according to Ewing [10].

\section{Antibiogram}

Phenotypic antibiotic susceptibility pattern was studied using antibiotic disk diffusion method according to Quinn et al. [11], against nine chemotherapeutic agents from seven antibiotic groups of the most frequently used in the field, as follows: Enrofloxacin (ENR) $(5 \mu \mathrm{g})$, norfloxacin (NOR) $(1.0 \mu \mathrm{g})$, amoxicillin/clavulanic acid (AMC) $(30 \mu \mathrm{g})$, tetracycline (TE) $(30 \mu \mathrm{g})$, doxycycline (DO) $(30 \mu \mathrm{g})$, gentamicin $(\mathrm{CN})(10 \mu \mathrm{g})$, cefuroxime $(\mathrm{CFX})(30 \mu \mathrm{g})$, trimethoprim $(\mathrm{T})(10 \mu \mathrm{g})$, and ciprofloxacin (CIP) $(5 \mu \mathrm{g})$. The results were interpreted according to the criteria recommended by CLSI [12].

Investigating the presence of ESBL-producing $E$. coli ESBL-producing phenotype in isolates was investigated by double disk synergy against AMC $(30 \mu \mathrm{g})$ along with third- and fourth-generation cephalosporin as follows: Cefepime (FEP) $30 \mu \mathrm{g} /$ fourth-generation, Cefotaxime (CTX) $40 \mu \mathrm{g} /$ third-generation, and ceftriaxone (CRO) $30 \mu \mathrm{g} /$ third-generation. The AMC disk was placed at the center of the plate and the three disks were placed at a distance of $1.5 \mathrm{~cm}$. Development of inhibition zone toward the clavulanate disk at $37^{\circ} \mathrm{C}$ after $24 \mathrm{~h}$ incubation was indicative of a potential ESBL positive organism [13]. The isolates that mostly demonstrated phenotypic extensive drug resistance together with phenotypic ESBL pattern were assessed for virulence by the embryo lethality assay (ELA).

\section{DNA extraction}

DNA extraction from samples was performed using the QIAamp DNA Mini kit (Qiagen, Germany, $\mathrm{GmbH}$ ) with modifications from the manufacturer's recommendations. Briefly, $200 \mu \mathrm{l}$ of the sample suspension was incubated with $10 \mu \mathrm{l}$ of proteinase $\mathrm{K}$ and $200 \mu \mathrm{l}$ of lysis buffer at $56^{\circ} \mathrm{C}$ for $10 \mathrm{~min}$. After incubation, $200 \mu 1$ of $100 \%$ ethanol was added to the lysate. The sample was then washed and centrifuged following the manufacturer's recommendations. Nucleic acid was eluted with $100 \mu$ of elution buffer provided in the kit.

Testing the presence of integrons one gene and ESBL $E$. coli by polymerase chain reaction (PCR)

\section{Oligonucleotide primer}

Primers supplied from Metabion (Germany) are listed in Table-1. Primers were utilized in a $25-\mu 1$ reaction containing $12.5 \mu \mathrm{l}$ of Emerald Amp Max PCR Master Mix (Takara, Japan), $1 \mu$ of each primer of 20 pmol concentrations, $4.5 \mu \mathrm{l}$ of water, and $6 \mu \mathrm{l}$ of DNA template. The reaction was performed in an Applied Biosystem 2720 thermal cycler, as shown in Table-1 $[14,15]$.

\section{Analysis of the PCR products}

The products of PCR were separated by electrophoresis on $1.5 \%$ agarose gel (Applichem, Germany, $\mathrm{GmbH}$ ), in $1 \times \mathrm{TBE}$ buffer at room temperature using gradients of $5 \mathrm{~V} / \mathrm{cm}$. For gel analysis, $20 \mu \mathrm{l}$ of the uniplex PCR products were loaded in each gel slot. Gelpilot 100 bp and 100 bp plus DNA ladders (Qiagen, Germany, GmbH) and GeneRuler 100 bp DNA ladder (Fermentas, Thermo Scientific, USA) were used to determine the fragment sizes. The gel was photographed by a gel documentation system (Alpha Innotech, Biometra), Germany, and the data were analyzed through computer software.

\section{ELA}

The virulence of E. coli isolates that demonstrated phenotypic attributes for ESBL was assessed by applying the chick embryo inoculation lethality test, as described by Oh et al. [16]. Sixty embryonated 


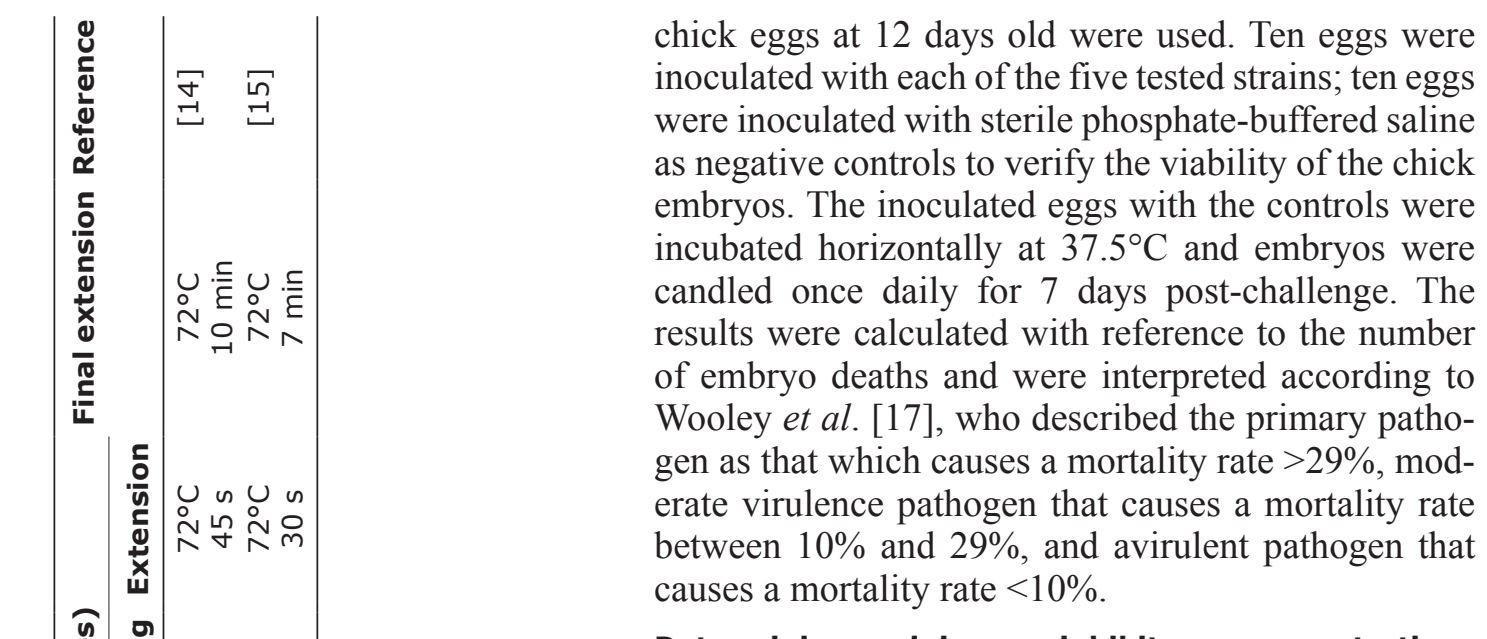

Determining minimum inhibitory concentrations (MICs)/minimum inhibitory concentration (MIC) of ESBL producers

MICs of the two isolates that showed the highest chick embryo lethality was determined in duplicates for each isolate, as described by Andrews and ChihCheng et al. $[18,19]$. The MIC was determined against $\mathrm{DO}$, as one of the common field prescribed antibiotics and also due to giving the highest sensitivity rate among the disk diffusion assay applied in the present study. Interpretation of the results of MIC was calculated according to a full range of MIC breakpoints in $\mu \mathrm{g} / \mathrm{ml}$ for $E$. coli and DO $(\mathrm{S}<4, \mathrm{I}=8, \mathrm{R}<16)$ according to CLSI [12]. The inoculum was prepared by direct colony suspension method, and MIC is defined as the lowest concentration of antibiotic that prevented macroscopically visible growth after $18 \mathrm{~h}$ of incubation. Minimum bactericidal concentrations (MBCs) were determined by subculturing $100 \mu \mathrm{L}$ from each well with no visible growth on Trypticase Soy Agar. MBC is defined as the lowest concentration of DO that prevented absolute growth on subculture after $18 \mathrm{~h}$ of incubation. MBC is identified by determining the lowest concentration of antibacterial agent that reduces the viability of the initial bacterial inoculum by a pre-determined reduction such as $\geq 99.9 \%$. The MBC is complementary to the MIC, whereas the MIC test demonstrates the lowest level of antimicrobial agent that greatly inhibits growth, the MBC demonstrates the lowest level of an antimicrobial agent resulting in microbial death [12].

\section{Results}

Examination of total 120 freshly dead turkey poults suffered from respiratory manifestations revealed the isolation of coagulase positive staphylococci, coagulase negative staphylococci, Campylobacter spp., Salmonella spp., Proteus spp., Pseudomonas spp., Klebsiella spp., and E. coli with the prevalence rates of $12 / 120(10 \%), 30 / 120(35 \%)$, 17/120 (14.2\%), 5/120 (4.1\%), 17/120 (14.2\%), 6/120 (5\%), 7/120 (5.8\%), and 18/120 (15\%), respectively. E. coli isolates were subjected for serotyping and characterization, while the rest of isolates were preserved to be investigated latter in further studies, as shown in Table-2. 
Serogrouping of $E$. coli isolates with regard to the somatic $\mathrm{O}$ antigen revealed that $\mathrm{O} 119$ was the most prevalent serogroup $6 / 18$ with a rate of $33.3 \%$, followed by $\mathrm{O} 6$ and $\mathrm{O} 8$, each with a detection rate of $4 / 18$ (22.2\%), O169 3/18 (16.7\%), while 1/18 (5.6\%) isolate was untypable, as shown in Table-3.

Phenotypic antibiotic susceptibility profile of isolates was studied by disk diffusion, the result revealed that $18 / 18(100 \%)$ of isolates demonstrated resistance against CFX, TE, and T, 16/18 (88.9\%) of isolates demonstrated resistance against AMC, ENR, and NOR, 14/18 (77.8\%) of isolates demonstrated resistance to DO and CIP, and 9/18 (50\%) of isolates showed resistance to $\mathrm{CN}$, the results also showed that $18 / 18(100 \%)$ of isolates demonstrated multidrug resistance (MDR) against chemotherapeutic agents belonged to more than 3 antibiotic groups, 9/18 (50\%) of isolates showed extensive resistance against the nine tested chemotherapeutic agents that belonged to seven antibiotic groups, as shown in Table-4.

In vitro susceptibility (double disk synergy test) of ESBL to beta-lactam antibiotics, the results showed

Table-2: Prevalence rate of isolates.

\begin{tabular}{lcc}
\hline Isolates & $\begin{array}{c}\text { Number of } \\
\text { isolates }\end{array}$ & $\begin{array}{c}\text { Prevalence rate } \\
\text { isolates (\%) }\end{array}$ \\
\hline Pseudomonas spp. & $6 / 120$ & 5 \\
Coagulase-positive & $12 / 120$ & 10 \\
staphylococci & $30 / 120$ & 35 \\
Coagulase-negative & & \\
staphylococci & $18 / 120$ & 15 \\
Escherichia coli & $5 / 120$ & 4.1 \\
Salmonella spp. & $17 / 120$ & 14.2 \\
Proteus spp. & $7 / 120$ & 5.8 \\
Klebsiella spp. & $17 / 120$ & 14.2 \\
Campylobacter spp. & & \\
\hline
\end{tabular}

Table-3: Serotyping of Escherichia coli isolates.

\begin{tabular}{lcc}
\hline $\begin{array}{l}\text { Identified } \\
\text { serotypes }\end{array}$ & $\begin{array}{c}\text { No. of } \\
\text { isolates }\end{array}$ & $\begin{array}{c}\text { Serotype distribution } \\
\text { rate }(\%)\end{array}$ \\
\hline O6 & $4 / 18$ & 22.2 \\
O119 & $6 / 18$ & 33.3 \\
O8 & $4 / 18$ & 22.2 \\
O169 & $3 / 18$ & 16.7 \\
Untypable & $1 / 18$ & 5.6 \\
Total & $18 / 18$ & 100 \\
\hline
\end{tabular}

that $6 / 18(33.3 \%), 8 / 18(44.4 \%)$, and 13/18 (72.2\%) of isolates demonstrated phenotypic pattern of ESBL producers by showing inhibition zones toward the central disk of AMC with FEB, with CTC, and with CRO, respectively, as shown in Table-5.

Testing the presence of beta-lactamase TEM $\left(b l a_{\text {TEM }}\right)$ gene and Class 1 integrons (int 1$)$ gene in E. coli isolates by PCR revealed that $17 / 18(94.4 \%)$ of isolates were positive for the studied genes, as shown in Table- 6 and Figures- 1 and 2.

E. coli isolates that demonstrated phenotypic attributes for extensive drug resistance, ESBL producing, and confirmed genotypic carriage for bla $_{\mathrm{TEM}}$ and int 1 genes were selected for virulence assessment by ELA; the results revealed that isolate number 5 (O119) and isolate number $6(\mathrm{O} 119)$ showed $100 \%$ lethality; the results also revealed that all isolates involved in the study were considered primary pathogens, as resulted in at least $60 \%$ embryo lethality. The isolates that showed $100 \%$ lethality (two isolates) were selected for MIC determination, as shown in Table-7.

MIC of DO $(1-32 \mu \mathrm{g} / \mathrm{ml})$ was studied against the two tested isolates (number 5 and number 6 ), the result demonstrated that isolate number 5 was considered susceptible, as the detected MIC breakpoint was $<4 \mu \mathrm{g} / \mathrm{ml}$, while the isolate number 6 was considered intermediate resistant as the detected MIC breakpoint was $=8 \mu \mathrm{g} / \mathrm{ml}$, Table- 8 .

Antibacterial agents are usually regarded as bactericidal if the $\mathrm{MBC}$ is no more than 4 times the MIC. The detected $\mathrm{MBC}$ for isolate number 5 was $8 \mu \mathrm{g} / \mathrm{ml}$, while the MBC for isolate number 6 was $16 \mu \mathrm{g} / \mathrm{ml}$, Table-9.

\section{Discussion}

In the present study, the bacteriological examination was applied to investigate the causative agents that are most probably implicated with the field problem reported in turkey flocks in Hefna, in winter 2018. Other studies attributed severe course of diseases with respiratory manifestations and high mortality rates in turkeys to concurrent infections with Klebsiella pneumoniae subsp. pneumoniae, E. coli, and Pseudomonas fluorescens; other researchers also recorded the isolation of Campylobacter jejuni from the liquid cecal content of diseased birds [20]. More studies identified

Table-4: Phenotypic susceptibility patterns of Escherichia coli isolates.

\begin{tabular}{llcc}
\hline Antibiotic group & Chemotherapeutic agent & Resistance rate & Sensitivity rate \\
\hline Penicillins & Amoxicillin/clavulanic acid & $16 / 18(88.9 \%)$ & $2 / 18(11.1 \%)$ \\
Cephalosporins & Cefuroxime & $18 / 18(100 \%)$ & $0 \%$ \\
Aminoglycosides & Gentamicin & $9 / 18(50 \%)$ & $9 / 18(50 \%)$ \\
Tetracycline & Tetracycline & $18 / 18(100 \%)$ & $0 \%$ \\
& Doxycycline & $14 / 18(77.8 \%)$ & $4 / 18(22.2 \%)$ \\
Quinolones & Enrofloxacin & $16 / 18(88.9 \%)$ & $2 / 18(11.1 \%)$ \\
& Norfloxacin & $16 / 18(88.9 \%)$ & $2 / 18(11.1 \%)$ \\
Diaminopyrimidine & Trimethoprim & $18 / 18(100 \%)$ & $0 \%$ \\
Fluoroquinolone & Ciprofloxacin & $14 / 18(77.8 \%)$ & $4 / 18(22.2 \%)$ \\
(Second-generation & & &
\end{tabular}

quinolone) 
Table-5: Results of studying Escherichia coli isolates for ESBL phenotypic activities.

\begin{tabular}{lcc}
\hline $\begin{array}{l}\text { Antibiotic } \\
\text { agent }\end{array}$ & $\begin{array}{c}\text { Number of sensitive } \\
\text { isolates }\end{array}$ & $\begin{array}{c}\text { Detection } \\
\text { rate (\%) }\end{array}$ \\
\hline Cefepime & $6 / 18$ & 33.3 \\
Cefotaxime & $8 / 18$ & 44.4 \\
Ceftriaxone & $13 / 18$ & 72.2 \\
\hline
\end{tabular}

$\mathrm{ESBL}=$ Extended-spectrum beta-lactamase

Table-6: Results of PCR detection of target genes.

\begin{tabular}{lc}
\hline Target gene & Detection rate \\
\hline bla $_{\mathrm{TEM}}$ & $17 / 18(94.4 \%)$ \\
Int1 & $17 / 18(94.4 \%)$ \\
\hline
\end{tabular}

$\mathrm{PCR}=$ Reverse transcriptase polymerase chain reaction

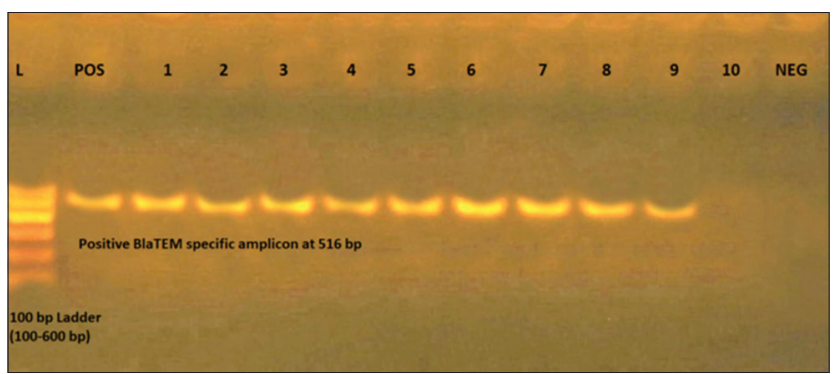

Figure-1: From the left to the right: Lane L: 100 bp ladder (100-600 bp), POS: Positive bla ${ }_{\text {TEM }}$ control at 516 bp, Lanes (1-9): Specific amplicon at $516 \mathrm{bp}$, Lane 10: Negative result no amplicon, NEG: Negative control.

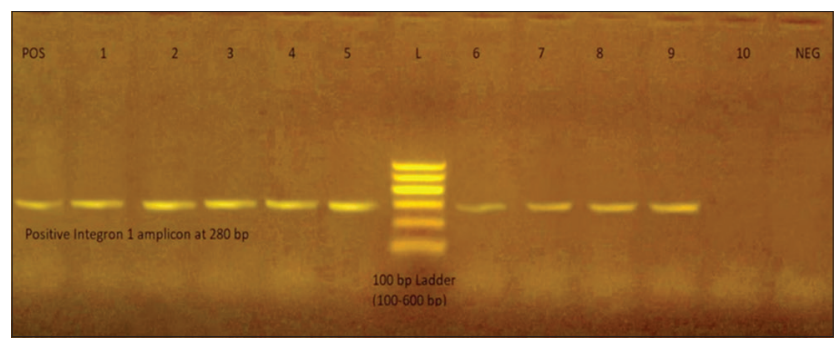

Figure-2: From the left to the right: POS: Positive integron 1 control at $280 \mathrm{bp}$, Lanes from (1-9): Specific amplicon at $280 \mathrm{bp}$, Lane L: $100 \mathrm{bp}$ ladder (100-600 bp), Lane (10): Negative result no amplicon.

that avian pathogenic E. coli, Staphylococcus aureus, and Ornithobacterium rhinotracheale were the three most frequently diagnosed pathogens of turkeys [21]. In the same instance, Salmonella spp. were isolated from turkeys with a prevalence rate of $31 / 98$ $(10.3 \%)$ [22]. Furthermore, scientific studies reported that poultry is implicated as a source of transmission of zoonotic MDR Proteus, which is considered the second causative agent of human urinary tract infection, consequently could be a problem for both veterinary and public health sectors [23]. In the same regard, Pseudomonas was isolated from diseased broilers suffered from respiratory manifestations, septicemia, and high mortality with a prevalence rate of $30 \%$ [24]. In the current study, E. coli isolates were characterized, while other bacterial isolates were preserved to be investigated in further studies.
Table-7: Results of ELA.

\begin{tabular}{lcccl}
\hline $\begin{array}{l}\text { Isolate } \\
\text { number }\end{array}$ & Serotype & $\begin{array}{c}\text { Number } \\
\text { of death }\end{array}$ & $\begin{array}{l}\text { Lethality } \\
\text { rate }(\%)\end{array}$ & ELA \\
\hline 3 & 06 & $6 / 10$ & 60 & $\begin{array}{l}\text { Primary } \\
\text { pathogen }\end{array}$ \\
5 & 0119 & $10 / 10$ & 100 & $\begin{array}{l}\text { Primary } \\
\text { pathogen } \\
\text { Primary } \\
\text { pathogen } \\
\text { Primary } \\
\text { pathogen } \\
6\end{array}$ \\
0119 & $10 / 10$ & 100 & 80 & $\begin{array}{l}\text { Primary } \\
\text { pathogen }\end{array}$ \\
7 & 08 & $8 / 10$ & 60 & \\
8 & 0169 & $8 / 10$ & &
\end{tabular}

$\mathrm{ELA}=$ Embryo lethality assay

Table-8: Determining MIC of Escherichia coli isolates.

\begin{tabular}{lcccccc}
\hline MIC & $\mathbf{1} \mathbf{2} \mathbf{4}$ & $\mathbf{1 6}$ & $\mathbf{3 2}$ & Interpretation \\
\hline Isolate no $5+++-$ & - & - & Sensitive \\
Isolate no $6++$ & + & - & - & Intermediate resistance \\
\hline MIC=Minimum inhibitory concentration, $+=$ Turbidity, & \\
-=No visible turbidity \\
Table-9: Determining MBC of Escherichia coli isolates. \\
\hline MBC & $\mathbf{1}$ & $\mathbf{2}$ & $\mathbf{4}$ & $\mathbf{8}$ & $\mathbf{1 6}$ & $\mathbf{3 2}$ \\
\hline Isolate no 5 & $5 \times 10^{3}$ & $3 \times 10^{2}$ & $2 \times 10^{2}$ & 0 & 0 & 0 \\
Isolate no 6 & $4 \times 10^{4}$ & $4 \times 10^{3}$ & $5 \times 10^{2}$ & $2 \times 10$ & 0 & 0
\end{tabular}

$\mathrm{MBC}=$ Minimum bactericidal concentration

Although E. coli is considered a member of the intestinal microbiota in vertebrates, including poultry, E. coli is one of the leading causes of economic losses in turkey production [25]. Moreover, E. coli are characterized by the presence of virulence genes encoding for important virulence factors as fimbriae, adhesion, toxins, siderophores, capsule, hemolysins, and invasion. Commensal, nonpathogenic E. coli may have a maximum of three virulence genes while avian enteropathogenic $E$. coli usually have tens of virulence genes [26]. Colibacillosis could be caused by a primary E. coli infection or secondary E. coli infection predisposed by viral and mycoplasma infection, or environmental stress factors, in which the birds suffered from respiratory manifestation, systemic infection, and probably fatal septicemia. The prevalence rate of $E$. coli recorded in the current study was $18 / 120(15 \%)$ of the total examined birds, while higher prevalence rate of avian pathogenic E. coli isolated from necropsied turkey poults was recorded by other studies, 13/15 (86.7\%) [27]. Other researchers also recorded higher prevalence rate $6 / 6(100 \%)$ of E. coli from turkey products [28].

It is of significance to identify the circulating serotypes implicated with recorded field cases in a particular geographic area and a chronologic period, thus may contribute to the epidemiological study, control and treatment recommendations. Studies applied on turkey colibacillosis cases reported the isolation of O18 and O111 [29], the identification of O78 and O111, and untypable isolates were also reported in 
other studies [30]. In the present study, serogrouping of $E$. coli isolates with regard to the somatic $O$ antigen revealed that $\mathrm{O} 119$ was the most prevalent serogroup 6/18 (33.3\%), followed by O6 and O8 each with a detection rate of 4/18 (22.2\%) and O $1693 / 18$ (16.7\%), while 1/18 (5.6\%) isolate was untypable.

The indiscriminate use of antibiotics in food animals including turkey flocks may select for resistant bacteria capable of causing human and animal diseases. Moreover, the circulation of resistant bacterial pathogens in farmed food animals including poultry may increase the risk of transmission of bacterial infections to human through food, direct or indirect contact between birds and human.

Phenotypic antibiotic susceptibility patterns of $E$. coli isolates were studied by disk diffusion and revealed that $18 / 18(100 \%)$ of isolates demonstrated resistance against $\mathrm{CFX}$, TE, and T, 16/18 (88.9\%) of isolates demonstrated resistance against AMC, ENR, and NOR, 14/18 (77.8\%) of isolates demonstrated resistance to DO and CIP, and 9/18 (50\%) of isolates showed resistance to CN. Similarly, other studies detected resistance against CTC, ampicillin, and TE with rates of $31 / 33(94 \%), 33 / 33(100 \%)$, and $28 / 33$ $(85 \%)$, respectively [28]. Resistance phenotypes to CTC was recorded by other studies, with a rate of $30 / 80(37.5 \%)$, with the conclusion that the majority of E. coli isolates were expressing ESBL MDR to amoxicillin, AMC, ceftazidime, and CTC with demonstration of positive synergy in 23/80 (29\%). Moreover, the isolates showed MDR, not only to beta-lactams but also to CIP, TE, and T/sulfamethoxazole [31]. It was also reported that $95.8 \%$ of APEC isolates showed resistance to TE, and DO, and penicillin and demonstrated resistance rates of $47.9 \%, 6.2 \%$, and $6.2 \%$ to $\mathrm{T}$, ENR, and CIP, respectively, but demonstrated full susceptibility to cephalosporin [32].

The current study also showed that 18/18 $(100 \%)$ of isolates demonstrated MDR against at least one chemotherapeutic agents belonged to three and more antibiotic classes. The study also revealed that 9/18 (50\%) of isolates showed extensive resistance against all the tested chemotherapeutic agents that belonged to seven antibiotic groups. In this regard, scientific studies reported the detection of ESBL $E$. coli isolates that demonstrated MDR against three and more antibiotic classes at least for one agent with multidrug patterns mostly demonstrated against (aminoglycosides, penicillin, TE, fluoroquinolones, and sulfonamides) in $96.1 \%$ and $82 \%$ of APEC isolates $[32,33]$.

In human medicine, two compartments have been suggested as habitats of ESBL-producing bacteria, one is nosocomial infections in hospitals and one is in the community as a result of consumption of contaminated food [34].

Furthermore, high frequency of ESBLproducing $E$. coli was isolated from broiler carcasses in Germany, Netherlands, and Spain $[1,35]$. In the present work, studying ESBL phenotypic attributes by double disk synergy technique revealed that $6 / 18$ (33.3\%), 8/18 (44.4\%), and 13/18 (72.2\%) of isolates demonstrated positive phenotypic pattern of ESBL producers by showing inhibition zones toward the central disk of amoxicillin/clavulanic acid and FEB, CTC, and CRO, respectively. Studies with similar purposes were applied in turkey products and detected ESBL-producing $E$. coli with a prevalence rate of $6 / 6$ $(100 \%)$, with a recorded resistance rate of $30 \%$ to ceftazidime [28]. Similarly, ESBL-producing E. coli were isolated with rates of $11 / 45(24 \%)$ and $6 / 20$ (30\%) from breeder farms [36].

Genotypic coding for ESBL producers include the genotypic attributes for $b l a_{\mathrm{CTX}-\mathrm{M}}, b l a_{\mathrm{TEM}}$, and $b l a_{\mathrm{SHV}}$ genes, in the present study investigation for the presence of $b l a_{\text {TEM }}$ gene was studied by PCR, the results demonstrated that $17 / 18(94.4 \%)$ of isolates were positive for $b l a_{\text {TEM }}$ gene. Other studies targeted the detection of $b l a$ genes $\left(b l a_{\mathrm{CTX}-\mathrm{M}}, b l a_{\mathrm{TEM}}\right.$, and $\left.b l a_{\mathrm{SHV}}\right)$ in $E$. coli isolates from poultry origin revealed the detection of $b l a_{\mathrm{TEM}}$ gene solely, and in concurrence with other bla genes members [31,36]. Moreover, high detection rates of $b l a_{\text {TEM }}$ gene $(70 \%, 100 \%)$ were reported [33,36].

Antibiotic resistance has been greatly linked to the dissemination of linked genes encoding resistance inserted in mobile genetic elements, mainly integrons. In the present study, integrons Class 1 gene was detected by PCR in 17/18 (94.4\%) of isolates, other study reported the detection of integrons of Class 1 in two isolates while detecting integrons of Class 2 in ten isolates, the same study also reported the disagreements of their recorded low detection rate of integrons Class 1 gene versus integrons Class 2 due to the results of many researches that concluded the dominance of integrons of Class 1 in animal-derived E. coli or in animal products as well as human isolates [37]. Lower detection rates of integrons Class 1 gene in E. coli isolates from turkey broilers and chicken breeders were recorded by other researchers $(0.9 \%$ and $12.5 \%)[32,36]$.

In the current study assessment of $E$. coli, isolates were of concern as a tool to associate their isolation to the reported field cases in the turkey farms in Hefna, Belbes, Sharkia (Egypt). Moreover, the virulence assessment was also required to assist the selection among the MDR isolates for use in determining MIC and MBC to recommend the most suitable antibiotic treatment.

In this regard, the study applied an ELA, as considered similar to intravenous, subcutaneous, and intratracheal challenge models and is capable of discriminating between virulent and avirulent avian E. coli isolates. Furthermore, ELA is regarded as sensitive and specific for virulence assessment in diagnostic laboratories $[16,38]$. The current observations revealed that $5 / 5(100 \%)$ of the tested isolates were considered as primary pathogens as $\mathrm{O} 6, \mathrm{O} 8$, and $\mathrm{O} 169$ as they 
contributed to $60 \%$ embryo lethality rate, while the two tested O119 caused 100\% embryo lethality rate.

Based on ELA results, the MIC and MBC for DO were applied to the two tested O119 isolates which resulted in the highest observed ELA (100\%) and the results indicated that DO has shown therapeutic effectiveness as one of the tested isolates demonstrated susceptibility and showed no viability with MIC at 4 and $\mathrm{MBC}$ at 8, while the other isolate demonstrated intermediate resistance with MIC 8 and MBC 16. In vitro study of DO and DO combinations effectiveness on MDR E. coli has the conclusion that although DO is an ancient and cheap antimicrobial agent, it exhibits a broad-spectrum effect against pathogens including Gram-negative and considered useful and even drug of choice in the treatment of MDR E. coli and other MDR pathogens [19].

\section{Conclusion}

Although penicillin and cephalosporins are considered the drugs of choice in poultry industry, the use of third and fourth generations cephalosporins, aminoglycosides and fluoroquinolones in veterinary medicine are believed to give rise for antimicrobialresistant bacterial strains that are implicated in economic losses in poultry production. Furthermore, impose the risk of treatment failure. Consequently, it is important to investigate whether ESBL producing E. coli and class 1 integrons carriers E.coli of poultry origin represent a zoonotic risk. Thus, monitoring and surveillance of antimicrobial resistance circulation in one health approach are recommended. Moreover, raising awareness for the appropriate use of antibiotics in both veterinary and human medicine is of importance.

\section{Authors' Contributions}

SE designed the study, collected the samples, and applied bacteriological examinations, wrote the manuscript. AHS applied the PCR testing. SE and AHS approved the final manuscript.

\section{Acknowledgment}

Profound gratitude and thanks are presented to Dr. Nayera, M. Al-Atfehy, the researcher in Reference Laboratory for Veterinary Quality Control, Dokki, Egypt, for her technical assistance. The study was conducted with resources of Reference Laboratory for Veterinary Quality Control on Poultry Production, Dokki, Egypt.

\section{Competing Interests}

The authors declare that they have no competing interests.

\section{Publisher's Note}

Veterinary World remains neutral with regard to jurisdictional claims in published institutional affiliation.

\section{References}

1. Rikke, H., Olsen, M.B., Ulrich, L., Brice, R. and Henrik, C. (2014) Extended-spectrum $\beta$-lactamase-producing Escherichia coli isolated from poultry: A review of current problems, illustrated with some laboratory findings. Avian Pathol., 43(3): 199-208.

2. Pitout, J.D.D. (2010) Infections with extended-spectrum B-lactamase-producing Enterobacteriaceae: Changing epidemiology and drug treatment choices. Drug, 70(3): 313-333.

3. Cohen, S.J., van den Munckhof, T., Voets, G., Scharringa, J., Fluit, A. and Leverstein-Van, H.M. (2012) Comparison of ESBL contamination in organic and conventional retail chicken meat. Int. J. Food Microbiol., 154(3): 212-214.

4. Randall, L.P., Clouting, C., Hoton, R.A., Coldham, N.G.,Wu, G., Clfton-Hadley, F.A., Davies, R.H. and Teale, C.J. (2011) Prevalence of Escherichia coli carrying extended-spectrum B-lactamases (CTX-M and TEM-52) from broiler chickens and turkeys in Great Britain between 2006 and 2009. J. Antimicrob. Chemother., 66(1): 86-95.

5. Barnes, H.J. and Gross, W.B. (1997) Colibacillosis. In: Calnek, B.W., editor. Disease of Poultry. $10^{\text {th }}$ ed. University Press, Ames, Iowa State. p131-141.

6. ISO/IEC. (2017) Microbiology of the Food Chain-Horizontal Method for the Detection, Enumeration and Serotyping of Salmonella Part 1. Detection of Salmonella spp.

7. ISO/IEC. (1999) Microbiology of Food and Animal Feeding Stuffs Horizontal Method for the Enumeration of Coagulase-positive staphylococci (Staphylococcus aureus and other Species) Part 1: Technique Using Baird-Parker Agar Medium.

8. Saif, Y.M. (2003) Diseases of Poultry. $11^{\text {th }}$ ed. Iowa State University Press, Ames.

9. ISO. (2006) Microbiology of Food and Animal Feeding Stuffs. Horizontal Method for the Detection of Thermotolerant Campylobacter. International Standards Organization, Geneva.

10. Ewing, W.H. (1986) Edwards and Ewing's Identification of Enterobacteriaceae. $4^{\text {th }}$ ed. Elsevier, New York.

11. Quinn, P.J., Carter, M.E., Markey, B. and Carter, G.R., editors. (1994) Listeria species. In: Clinical Veterinary Microbiology. Mosby International Limited, London.

12. CLSI. (2015) Performance Standards for Antimicrobial Susceptibility Testing; Twenty First Informational Supplement, M100S21. Standard by Clinical and Laboratory Standards Institute, Wayne, PA.

13. Iqbal, R., Ikram, N., Shoaib, M., Muhammad, J.A., Raja, T.M., Abid, A.N., Aanam, A., Bushra, I. and Faiza, N. (2017) Phenotypic confirmatory disk diffusion test (PCDDT), double-disk synergy test (DDST), E-test OS diagnostic tool for detection of extended-spectrum beta-lactamase (ESBL) producing uropathogens. J. Appl. Biotechnol. Bioeng., 3(3): 344-349.

14. Colom, K., Pèrez, J., Alonso, R., Fernández-Aranguiz, A., Lariňo, E. and Cisterna, R. (2003) Simple and reliable multiplex PCR assay for detection of $b l a_{\mathrm{TEM}}, b l a_{\mathrm{SHV}}$ and $b l a_{\mathrm{OXA}-1}$ genes in Enterobacteriaceae. FEMS Microbiol. Lett., 223(2): 147-151

15. Kashif, J., Buriro, R., Memon, J., Yaqoob, M., Soomro, J., Dongxue, D., Jinhu, H. and Liping, W. (2013) Detection of class 1 and 2 integrons, $\beta$-lactamase genes and molecular characterization of sulfonamide resistance in Escherichia coli isolates recovered from poultry in China. Pak. Vet. J., 33(3): 321-324.

16. Oh, J.Y., Kang, M.S., Yoon, H., Choi, H.W., An, B.K., Shin, E.G., Kim, Y.J., Kim, M.J., Kwon, J.H. and Kwon, Y.K. (2012) The embryo lethality of Escherichia coli isolates and its relationship to the presence of virulence-associated genes. Poult. Sci., 91(2): 370-375.

17. Wooley, R.E., Gibes, P.S., Brown, T.P. and Maurer, J.J. 
(2000) Chicken embryo lethality assay for determining the virulence of avian Escherichia coli isolates. Avian Dis., 44(2): 318-324.

18. Andrews, J.M. (2001) Determination of minimum inhibitory concentration. J. Antimicrob. Chemother., 48(1): 5-16.

19. Chih-Cheng, L., Chi-Chung, C., Hui-Ling, H., Yin-Ching, C. and Hung-Jen, T. (2016) The role of doxycycline in the therapy of multidrug-resistant $E$. coli an in vitro study. Sci. Rep., 6: 31964.

20. Hinz, K.H., Heffels-Redmann, U. and Pöppel, M. (1992) Multi-causal infectious respiratory tract disease of young fattening turkeys. Dtsch. Tierarztl. Wochenschr., 99(2): 75-78.

21. Agnes, A., Carolee, C. and Dave, L. (2013) Antimicrobial therapy of selected diseases in Turkeys, laying hens, and minor poultry species in Canada. Can. Vet. J., 54(11): 1041-1052.

22. Annemarie, K., Andreas, S., Reiner, H. and Bernd-Alois, T. (2013) Salmonella prevalence in Turkey flocks before and after implementation of the control program in Germany. Agriculture, 3(3): 342-361

23. Mostafa, N. (2013) Antimicrobial resistance of porteus isolates from poultry. Eur. J. Exp. Bio., 3(6): 499-500.

24. Satish, S. and Priti, M. (2015) Pseudomonas aeruginosa infection in broiler chicks in Jabalpur. Int. J. Ext. Res., 6: 37-39.

25. Hafez, H.M. (2005) Current Knowledge and Prospective Risk Analysis Related to Ongoing Turkey Diseases. In: Proceedings of $14^{\text {th }}$ International Congress of the World Poultry Association, Istanbul, Turkey. Lebib Yalkin Yaimlari ve Basim Isleri Anonim Sirketi, Istanbul, Turkey. p138-149.

26. Pires, D.S.T., Bisgaard, M. and Christensen, H. (2013) Genetic diversity and virulence profiles of Escherichia coli causing salpingitis and peritonitis in broiler breeders. Vet. Microbiol., 162(2-4): 873-880.

27. Davide, G., Caterina, L., Patrizia, P., Giulia, R., Giovanni, O. and Elena, C. (2013) Characterization and antimicrobial resistance analysis of avian pathogenic Escherichia coli isolated from Italian. Poult. Sci., 92(10): 2661-2667.

28. Olsen, R.H., Chadfeild, M.S., Christensen, J.P., Scheutz, F., Christensen, H. and Bisgaard, M. (2011) Clonality and virulence traits of Escherichia coli associated with hemorrhagic septicemia in Turkeys. Avian Pathol., 40(6): 587-595.

29. Chiara, B., Felix, R., Daniele, M., Filippo, G., Antonio, P., Gunter, K. and Victoria, A. (2014) ESBL-producing bacteria and MRSA isolated from poultry and Turkey products imported from Italy. CZECH J. Food Sci., 33(2): 97-102.
30. Bardul, H., Linus, S., Asa, M., Mirva, D., Jorge, H., Jonas, W., Munirul, A. and Bjorn, O. (2012) Antimicrobial drug-resistant Escherichia coli in wild birds and freerange poultry, Bangladesh. Emerg. Infect. Dis., 18(12): 2055-2058

31. Abbassi, M.S. (2017) ESBL/Cephalosporinase-producing Escherichia coli from retail poultry meat in Tunisia: Predominance of $b l a_{\text {СTX-M }}$ gene and multidrug resistance. $J$. Microbes Microbiol. Tech., 1(1): 102.

32. Piccirillo, A., Giovanardi, D., Dotto, G., Grilli, G., Montessissa, C., Boldrin, C., Salata, C. and Giacomelli, M. (2014) Antimicrobial resistance and class 1 and 2 integrons in Escherichia coli from meat turkeys in Northern Italy. Avian Pathol., 43(5): 396-405.

33. Hoepers, P.G., Silva, P.L., Rossi, D.A., Valadares, J., Ferreira, B.C. and Zuffo, J.P. (2018) The association between extended-spectrum beta-lactamase (ESBL) and ampicillin $\mathrm{C}(\mathrm{AmpC})$ beta-lactamase genes with multidrug resistance in Escherichia coli isolates recovered from turkeys in Brazil. Br. Poult. Sci., 59(4): 396-401.

34. Platteel, T.N., Leverstein-Van Hall, M.A., Cohen Stuart, J.W., Voets, G.M., van den Munckhof, M.P., Scharringa, J., van de Sande, N., Fluit, A.C., Bonten, M.J. and ESBL National Surveillance Working Group. (2013) Differences in the antibiotic susceptibility of human Escherichia coli with poultry-associated and non-poultry-associated extended-spectrum beta-lactamases. Eur. $J$. Clin. Microbiol. Infect. Dis., 32(8): 1091-1095.

35. Wasyl, D.,Hoszowski,A.,Zajac, M. and Szulowski, K. (2013) Antimicrobial resistance in commensal Escherichia coli isolated from animals at slaughter. Front. Microbiol., 4: 221.

36. Kilani, H., Abbassi, M.S., Ferjani, S., Mansouri, R., Sghaier, S., Ben Salem, R., Jaouani, I., Douja, G., Brahim, S., Hammami, S., Ben Chehida, N. and Boubaker, I.B. (2015) Occurrence of $b l a_{\text {СTX-M-1 }}$, qnrB1 and virulence genes in avian ESBL-producing Escherichia coli isolates from Tunisia. Front. Cell Infect. Microbiol., 5 : 38.

37. Cergole-Novella, M.C., Guth, B.E., Castanheira, M., Carmo, M.S. and Pignatari, A.C. (2010) First description of bla $a_{\text {CTX-M-14 }}$-and bla $a_{\text {CTX-M-15 }}$-producing Escherichia coli isolates in Brazil. Microb. Drug Resist., 16(3): 177-184.

38. Nolan, L.K., Wooley, R.E., Brown, J., Spears, K.R., Dickerson, H.W. and Dekich, M. (1992) Comparison of a complement resistance test, a chicken embryo lethality test $\mathrm{a}$, and the chicken lethality test for determining virulence of avian Escherichia coli. Avian Dis., 36(2): 395-397.

\section{$* * * * * * * *$}

